\title{
Stunting and its Determinants among Governmental Primary School Children in Egypt: A School-based Cross-sectional Study
}

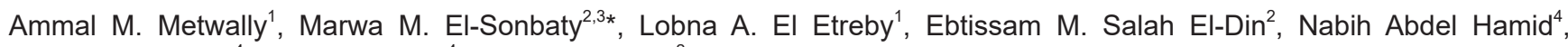 \\ Hanan A. Hussien ${ }^{4}$, Amal Hassanin ${ }^{4}$, Zeinab M. Monir ${ }^{2}$ \\ ${ }^{1}$ Department of Community Medicine, Medical Research Division, National Research Centre, (Affiliation ID: 60014618), Dokki, \\ Cairo, Egypt; ${ }^{2}$ Department of Child Health, Medical Research Division, National Research Centre, (Affiliation ID: 60014618), \\ Dokki, Cairo, Egypt; ${ }^{3}$ Department of Pediatrics, College of Medicine, Taibah University, Madinah, KSA; ${ }^{4}$ Agricultural Research \\ Centre, Giza, Egypt
}

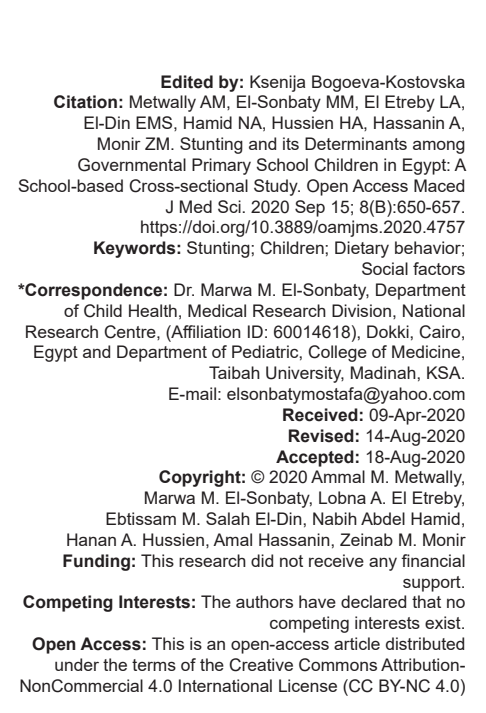

\section{Abstract}

BACKGROUND: In developing countries, stunting among children is a major public health concern. It affects all aspects of children's lives; its effects are not constrained to physical wellbeing but reach out to mental, social, and spiritual wellbeing.

AIM: The aim of this study is to determine the prevalence of stunting in some of the Egyptian governmental primary school children and its nutritional and socioeconomic determinants.

METHODS: A cross-sectional observational study was conducted on primary school children aged 6-12 years. General demographic, socioeconomic, and anthropometric data, as well as dietary pattern, were collected.

RESULTS: Out of 1740 children, $7.8 \%$ were stunted. Not eating eggs and dairy products had the most profound effect on stunting in children $(p<0.001)$. Not having meals on time, skipping breakfast, and having $<3$ meals per day were predictors of stunting $(p=0.003, p=0.00$, and $p=0.008$, respectively). Mother's education $(p=0.005)$ followed by family income $(p=0.007)$ was the most affecting social factors.

CONCLUSION: There are many nutritional factors associated with stunting as skipping breakfast, not having meals on time, and having $<3$ meals per day. Scarcity in nutritive foods as eggs and dairy products and increased soft drink intake can lead to stunting. There are many enabling social factors for stunting as mother's education and family income. However, the effects of these factors can be modified by health awareness.

\section{Introduction}

The concern about undernutrition is due to a long series of devastating effects on early childhood growth and development, contributing not only to infant and child mortality but also to physical and cognitive developmental impairments among children. As child malnutrition leads to an infinite cycle of malnutrition throughout the life cycle of the child later on in his life, this might create considerable risks for future mothers. This is especially true, looking at stunting, wasting, and micronutrient deficiencies [1].

Overcoming undernutrition in all its forms is linked to sustainable development goals (SDG) 1 (no poverty) and (SDG) 2 (zero hunger) [2]. Children are the hope of the future and resemble seeds that, if well taken care of, will flourish and open unlimited possibilities for a better society in terms of health, lifestyle, and building capacities.
Child stunting can be due to many factors, including socioeconomic status, dietary intake, infections, maternal nutritional status, infectious diseases, micronutrient deficiencies, and the environment [3]. In 2016, there were 87 million stunted children in Asia versus 59 million lived in Africa and 6 million lived in Latin American and the Caribbean regions [4].

School children are the most important segment of Egyptian society. They represent $40.1 \%$ of the total population. In 2018, their number reached 38.9 million [5]. The physical growth and nutritional status of school-aged children are considered to be of utmost significance as it presents the general health status of the whole community. Good nutrition is also a determinant of healthy growth of mind and body in all stages of life, especially in the early stages of life [6], [7], [8], [9], [10], [11].

Since the degree of stunting is likely to increase with the advancement of the school-age years [12], 
it was important to focus on studying the nutritional status of children of ages 6-12 years, especially with the limited literature about studying this group. In addition, it is well-known that both girls and boys of this age group have the potential of experiencing catch-up growth to be brought to the normal ranges of height for age. That is why the problem of child stunting in Egypt has to be sufficiently identified among the school-age group (6-12 years) as well as the reasons behind it.

The aim of the study is to determine the prevalence of stunted children among Egyptian governmental primary school-aged children and its nutritional determinants as taking breakfast, the number of meals per day, the impact of daily and weekly intake of nutrient-rich food versus energy-dense food on stunting, and also the socioeconomic determinants as mother education and family income.

\section{Methodology}

\section{Study design}

The study was a cross-sectional conducted in three governorates representing different geographical regions in Egypt with different nutritional habits that were selected randomly, one representing lower Egypt (Behaira governorate), one representing the Coastal region (Damietta governorate), and one representing upper Egypt (Fayoum governorate).

\section{Sampling frame and sampling unit}

Three sampling frames were chosen. The first sampling frame used was based on stratification of the Egyptian governorates into three strata representing rural Lower Egypt, Coastal region, and upper Egypt governorates. The second sampling frame was based on a comprehensive list of the governorates as per regions. The third sampling frame was the stratification of listing the units to be sampled (governmental primary school children). For the third sampling frame, a logical order was used for schools and then a cluster of schools was chosen with probability proportion to size from that listing. This ensured that the units were evenly distributed within the listing and avoided the possibility that, due to chance, one type of school ends up being under-represented.

The selection along all the stages was random one; governorates that were randomly selected and matched the inclusion criteria were Behaira, Damietta, and Fayoum governorates representing lower Egypt, Coastal region, and upper Egypt governorates respectively.

Figure 1 presents the probability proportion to the size distribution of sample along the three governorates of Egypt.

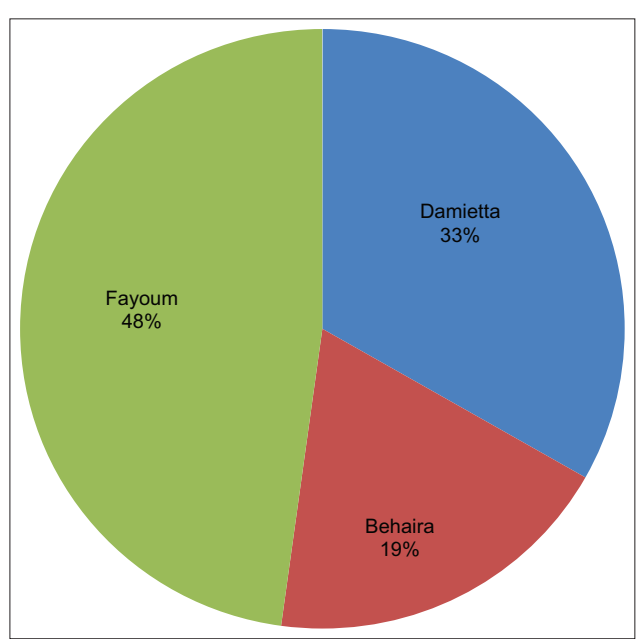

Figure 1: Sample distribution

\section{Sample size}

A sample size of 1710 produces a two-sided $98 \%$ confidence interval with a width equal to 0.030 as a margin of error when the sample proportion is 0.080 [13], [14]. The sample was rounded to be 1740 to ensure the number of clusters.

The proportion used for sample size calculation was according to the findings of an Egyptian study that was done to detect stunting and underweight among children in $4^{\text {th }}$-grade primary school children, which found that the percentage of stunted children was $7.6 \%$ and the under-weight children $1.1 \%$ among 903 sampled children representing a small percentage for both [6]. Accordingly, the calculated sample size was big enough to detect the burden of undernutrition among primary school children.

\section{Sample size calculation was as follow}

\begin{tabular}{llllllll}
\hline Sample & & & & & & & \\
\hline Confidence & Size & Target & Actual & Proportion & Lower & Upper & Width if \\
\hline Level & $(\mathrm{N})$ & Width & Width & $(\mathrm{P})$ & Limit & Limit & $\mathrm{p}=0.5$ \\
0.975 & 1710 & 0.030 & 0.030 & 0.080 & 0.066 & 0.096 & 0.055 \\
\hline
\end{tabular}

\section{Study participants}

The choice of subjects was random in the form of clusters (6 clusters/each school); each cluster was formed of 10 students from each grade with a total of 60 children/each primary school children. The actual total number of the randomly surveyed schools was 29 schools distributed along 16 districts within the three governorates with average 1-3 schools/ district and 8-10 schools/each of the selected governorates according to the number of schools per district.

\section{Inclusion criteria}

Apparently healthy prepubescent boys and girls in primary schools within six grades. The primary school children were aged 6-12 years. 


\section{Exclusion criteria}

Students proved to have any endocrinal disorders or syndromes (recorded among the children's own school health files) were excluded from the study.

\section{Methods}

\section{An assessment questionnaire}

Was used which included: General demographic and socioeconomic data including order of child among his siblings, family size, family income, father's income, and mother's education. The socioeconomic level of the participants was calculated according to Egypt's Central Agency for Public Mobilization and Statistics [15].

\section{Dietary pattern}

A rapid ethnographic study was done in each community. It was conducted by senior nutritionists to obtain: Qualitative information about the different items of food and beverages consumed by children. The dietary pattern was used to assess cultural preferences, availability of different food items, dietary habits and behavior of children (skipping breakfast [whether taken or not], number of meals consumed per day [3-5 meals], eating meal at school through school day).

The frequency of food eaten per week which is called share of the stomach was determined.

Frequency of nutrient-rich foods (vegetables, fruits, nutrient-rich sources of protein, and dairy products) eaten per week compared to energy-dense foods (French fries, Chips, sugar-sweetened beverages (SSB), Biscuits, Chocolate, Pancakes/cakes, Ice cream, and Candies) was analyzed.

Pre-testing of the questionnaire was done for 100 students that were excluded from data analysis.

\section{Nutritional status assessment}

The assessment was carried out through anthropometric measurements of height. All measurements were made as per the techniques described in the anthropometric standardization reference manual [16]. Standardization was made during taking anthropometric measurements; for height, it was taken during morning hours on an empty stomach before having breakfast or any meal at their school, within a minimum $8 \mathrm{~h}$ after micturition and defecation and after their morning exercises at school. All scores were calculated based on the WHO growth standards with the help of Anthro-Program of PC [17].

- Height/age Z-score (HAZ): Children whose $H A Z<-2$ are considered stunted.
Anthropometric indicators provide measures of nutritional status based on measures of body size relative to their distribution in a reference population. Anthropometric indicators measure achieved nutritional status rather than nutrition inputs, are less subject to measurement error than dietary intake data, and also are less expensive.

Growth assessment best defines the health and nutritional status of a child because disturbances in health and nutrition, regardless of their etiology, invariably affect child growth. WHO has been recommending that a single international reference population be used worldwide, with common indicators and cut-offs, and set standard methods to analyze child growth data [18]. Height-for-age is used to indicate past nutritional deficits as it reflects a child's nutritional history.

\section{Ethical issues}

The study was approved by the Ministry of Education. Moreover, the Medical Research Ethics Committee of the National Research Centre with ethical approval number of 19068. Consent from the children's guardians was taken and the conduct of the study complied with the International Ethical Guidelines for Biomedical Research Involving Human Subjects [19].

\section{Statistical analysis}

Data were analyzed using Statistical Package for the Social Sciences (SPSS) version 21.0 software. All data were represented by percentages and comparisons between groups were done using the odds ratio (ref, to study the association of the studied parameters with stunted). Probability values $(P)$ of $<0.05$ were regarded as statistically significant. Logistic regression analysis and was done to assess the contribution of each independent variable in explaining the predictors of stunting [20], [21], [22].

\section{Results}

According to anthropometric measurements, the height of children was classified as being normal or stunted.

The prevalence of stunting in our study was $7.8 \%$. Factors affecting physical growth were classified into nutritional factors and social factors.

When children did not have breakfast and their number of meals was $<3$ meals per day, the risk of stunting was 4 times more than those who had breakfast and their number of meals was more than 
three per day $(\mathrm{OR}=4.5)$. Skipping breakfast or morning snack, not having meals on time and number of meals $<3$ carried more than double risk of being stunted than having breakfast or morning snack, having more than 3 meals and having meals on time $(\mathrm{OR}=2.75,2.8,2.06)$ respectively (Table 1).

Table 1: Effect of dietary behavior on stunting

\begin{tabular}{|c|c|c|c|}
\hline Parameters & $\begin{array}{l}\text { Stunted } \\
(n=135) 7.8 \%\end{array}$ & $\begin{array}{l}\text { Normal } \\
(n=1605) 92.2 \%\end{array}$ & $\begin{array}{l}\text { Test of sig. } \\
\text { Odds ratio }(\mathrm{Cl})\end{array}$ \\
\hline \multicolumn{4}{|l|}{ Breakfast } \\
\hline No $(n=480)$ & $61(45.19)$ & $419(26.1)$ & \multirow{2}{*}{$\begin{array}{l}\mathrm{OR}=2.33 \\
(1.63-3.33)^{*}\end{array}$} \\
\hline Yes $(n=1260)$ & $74(54.81)$ & $1186(73.89)$ & \\
\hline \multicolumn{4}{|l|}{ Number of meals } \\
\hline$<3(n=210)$ & $69(51.11)$ & $541(33.7)$ & \multirow{2}{*}{$\begin{array}{l}\mathrm{OR}=2.06 \\
(1.45-2.93)^{\star}\end{array}$} \\
\hline$\geq 3(n=1530)$ & $66(48.89)$ & $1064(66.29)$ & \\
\hline \multicolumn{4}{|c|}{ Breakfast and/or morning snacks } \\
\hline No $(n=308)$ & $47(34.81)$ & $261(16.26)$ & \multirow{2}{*}{$\begin{array}{l}\mathrm{OR}=2.75 \\
\left(1.88-4.01^{\star}\right)\end{array}$} \\
\hline Yes $(n=1432)$ & $88(65.19)$ & $1344(83.74)$ & \\
\hline \multicolumn{4}{|l|}{ Breakfast + number of meal } \\
\hline $\begin{array}{l}\text { No breakfast + number of } \\
\text { meals }<3(n=154)\end{array}$ & $45(33.33)$ & $109(6.79)$ & \multirow[t]{2}{*}{$\begin{array}{l}\mathrm{OR}=4.5 \\
\left(2.89-7.02^{\star}\right)\end{array}$} \\
\hline $\begin{array}{l}\text { Breakfast }+ \text { number of } \\
\text { meals } \geq 3(n=655)\end{array}$ & $55(66.67)$ & $600(93.21)$ & \\
\hline \multicolumn{4}{|l|}{ Source of breakfast } \\
\hline Other $(n=1698)$ & $133(98.6)$ & 1565 (97.5) & \multirow{2}{*}{$\begin{array}{l}\mathrm{OR}=1.7 \\
(0.40-7.11)\end{array}$} \\
\hline Home $(n=42)$ & $2(1.4)$ & $40(2.5)$ & \\
\hline \multicolumn{4}{|l|}{ Meals on time } \\
\hline No $(n=339)$ & $52(38.2)$ & $287(17.9)$ & \multirow{2}{*}{$\begin{array}{l}\mathrm{OR}=2.8 \\
(1.99-4.13)^{*}\end{array}$} \\
\hline Yes $(n=1401)$ & $83(61.8)$ & $1318(82.1)$ & \\
\hline \multicolumn{4}{|l|}{ Mid-day snack } \\
\hline No $(n=179)$ & $15(10.8)$ & 164(10.2) & \multirow{2}{*}{$\begin{array}{l}\mathrm{OR}=1.09 \\
(0.62-1.92)\end{array}$} \\
\hline Yes $(n=1561)$ & $120(89.2)$ & $1441(89.8)$ & \\
\hline \multicolumn{4}{|c|}{ Snacks/anything between meals } \\
\hline No $(n=321)$ & $24(17.9)$ & $297(18.5)$ & \multirow{2}{*}{$\begin{array}{l}\mathrm{OR}=0.95 \\
(0.60-1.51)\end{array}$} \\
\hline Yes $(n=1419)$ & $111(82.1)$ & $1308(81.5)$ & \\
\hline \multicolumn{4}{|c|}{ Snacks before sleep sweets, chips...etc.) } \\
\hline Yes $(n=743)$ & $63(46.3)$ & $680(42.4)$ & \multirow{2}{*}{$\begin{array}{l}\mathrm{OR}=1.19 \\
(0.83-1.69)\end{array}$} \\
\hline No $(n=997)$ & $72(53.7)$ & $925(57.8)$ & \\
\hline \multicolumn{4}{|l|}{ Having dinner } \\
\hline No $(n=347)$ & $29(21.5)$ & $318(19.8)$ & \multirow[t]{2}{*}{$\begin{array}{l}\mathrm{OR}=1.1 \\
(0.72-1.7)\end{array}$} \\
\hline Yes $(n=1393)$ & $106(78.5)$ & $1287(80.2)$ & \\
\hline
\end{tabular}

Intake of nutrient-rich foods (vegetables, fruits, nutrient-rich sources of protein, and dairy products) was more in normal children (50\%) contrary to energy-dense food (French fries, Chips, SSB, Biscuits, Chocolate, Pancakes/cakes, Ice cream, and Candies) and carbohydrate in grains which were eaten more by stunted children $(30 \%$ and $42 \%$, respectively). Half of the food consumed by normal children was nutrient-rich due to the consumption of dairy and beans or meat versus $28 \%$ of stunted children. This is considered the weekly share of the stomach. Beverages and chocolate were consumed more than once every day in $81 \%$ and $66 \%$ of stunted children versus $68 \%$ and $64 \%$ of normal children, respectively (Table 2 ).

The majority of the social factors had a profound effect on stunting. Having illiterate mothers or mothers who could just read and write, low-income families, and large family size carried more than 3 times the risk of having stunted children than having highly educated mothers, middle-income families, and smallsized families $(\mathrm{OR}=3.78, \mathrm{OR}=3.24$, and $\mathrm{OR}=3.13$, respectively). Having illiterate fathers or fathers who could just read and write and is the third or more in order among siblings carried more than double risk of being stunted $(\mathrm{OR}=2.64$ and $\mathrm{OR}=2.49$, respectively) (Table 3).
Table 2: Comparison of the weekly and daily dietary intake of nutrient-rich foods versus energy-dense food between stunted and normal children

\begin{tabular}{|c|c|c|c|}
\hline Parameters & $\begin{array}{l}\text { Stunted } \\
(n=135) 7.8 \%\end{array}$ & $\begin{array}{l}\text { Normal } \\
(n=1605) 92.2 \%\end{array}$ & Odds ratio \\
\hline \multicolumn{4}{|c|}{$\begin{array}{l}\text { Diversity of nutrient-rich foods (vegetables, fruits, nutrient-rich sources } \\
\text { of protein, and dairy products) eaten per week }\end{array}$} \\
\hline Nutrient rich foods (overall) & $38(28)$ & $803(50)$ & $2.56(1.74-3.77)$ \\
\hline Energy dense food & $41(30)$ & $385(24)$ & $0.72(0.49-1.06)$ \\
\hline Carbohydrates/grains & $56(42)$ & $417(26)$ & $0.49(0.34-0.71)^{*}$ \\
\hline \multicolumn{4}{|c|}{$\begin{array}{l}\text { Share of the stomach (frequency of nutrient-rich foods as per } \\
\text { food groups eaten per week) }\end{array}$} \\
\hline Dairy & $8(6)$ & $289(18)$ & $3.49(1.69-7.20)^{x}$ \\
\hline Meat/beans/eggs & $16(12)$ & $321(20)$ & $1.86(1.09-3.18)^{x}$ \\
\hline Fruits & $9(7)$ & $112(7)$ & $1.05(0.52-2.12)$ \\
\hline Vegetables & $5(3)$ & $81(5)$ & $1.38(0.55-3.47)$ \\
\hline \multicolumn{4}{|c|}{ Proportion and types of the most weekly consumed unhealthy food among children } \\
\hline Weekly consumption & & & Odds ratio \\
\hline French fries & $118(87)$ & $1396(87)$ & $1.03(0.61-1.76)$ \\
\hline Chips & $113(84)$ & $1332(83)$ & $1.05(0.65-1.69)$ \\
\hline $\begin{array}{l}\text { Sugar sweetened } \\
\text { beverages }\end{array}$ & $109(81)$ & $1091(68)$ & $1.97(1.27-3.07)^{\prime}$ \\
\hline Biscuits & $89(66)$ & $1075(67)$ & $0.95(0.67-1.32)$ \\
\hline Chocolate & $89(66)$ & $1027(64)$ & $1.09(0.75-1.58)$ \\
\hline Pancakes/cakes & $81(60)$ & $995(62)$ & $0.92(0.64-1.32)$ \\
\hline Ice cream & $74(55)$ & $931(58)$ & $0.88(0.62-1.25)$ \\
\hline Candies & $58(43)$ & $738(46)$ & $0.88(0.62-1.26)$ \\
\hline
\end{tabular}

The important factors having a significant effect on the height of children were having meals on time ( $p<0.001)$, having breakfast in addition to having a morning snack $(p=0.002)$, or having breakfast alone $(p=0.003)$. The number of meals eaten by the child $(p=0.008)$ and eating eggs and dairy products had a profound effect $(p<0.001)$, drinking soft drinks $p=0.007$, concerning social factors mother education followed by family income then father education was the priority index for having stunted children $(O R=0.005$, $\mathrm{OR}=0.007$, and $\mathrm{OR}=0.009$ ), respectively (Table 4).

Table 3: Effect of social factors on stunting

\begin{tabular}{|c|c|c|c|}
\hline Parameters & $\begin{array}{l}\text { Stunted } \\
(n=135) 7.8 \%\end{array}$ & $\begin{array}{l}\text { Normal } \\
(n=1605) 92.2 \%\end{array}$ & $\begin{array}{l}\text { Test of sig. } \\
\text { Odds ratio }(\mathrm{Cl})\end{array}$ \\
\hline \multicolumn{4}{|l|}{ Child order } \\
\hline Child order $(\geq 3)(n=715)$ & $89(65.93)$ & $626(39)$ & $\mathrm{OR}=2.49$ \\
\hline Child order $(1-2)(n=1035)$ & $56(34.07)$ & $979(61)$ & $(1.75-3.52)^{*}$ \\
\hline \multicolumn{4}{|l|}{ Family size* } \\
\hline Large family $(n=866)$ & $100(74.07)$ & 766 (47.73) & $O R=3.13$ \\
\hline Small family $(n=874)$ & $35(25.93)$ & $839(52.27)$ & $(2.10-4.66)^{*}$ \\
\hline \multicolumn{4}{|l|}{ Family income $^{\star \star}$} \\
\hline Low-income family $(n=836)$ & $99(73.33)$ & $737(45.91)$ & $O R=3.24$ \\
\hline Middle-income Family(n=904) & $36(26.67)$ & $868(54.08)$ & $(2.18-4.80)^{*}$ \\
\hline \multicolumn{4}{|l|}{ Mother education ${ }^{\star \star *}$} \\
\hline Illiterate or read and write $(n=829)$ & 105 (77.78) & $724(45.12)$ & $O R=3.78$ \\
\hline High education $(n=911)$ & $30(22.22)$ & $781(54.89)$ & $(2.49-5.74)^{\star}$ \\
\hline \multicolumn{4}{|l|}{ Father education ${ }^{\star \star \star}$} \\
\hline Illiterate or read and write $(n=995)$ & $101(74.81)$ & $894(55.7)$ & $\mathrm{OR}=2.64$ \\
\hline High education $(n=708)$ & $29(25.19)$ & $679(44.3)$ & $(1.73-4.04)$ \\
\hline
\end{tabular}

Negative means: For continuous data with the increase, there is a decrease in the risk of stunting, and for dichotomous data, it means that with its absence, the risk of stunting increases.

\section{Discussion}

Nutritionalstatusisastrongdeterminantofhealth, neurocognitive performance, and school achievement of school-aged children [6], [7], [8], [9], [10], [11]. In 
addition to this, childhood undernutrition can impact adults' salaries and families' incomes [23].

Table 4: Logistic regression of factors affecting height for age Z scores

\begin{tabular}{lll}
\hline Parameter & B & Sig. \\
\hline Breakfast & 0.840 & 0.003 \\
School meal & -0.522 & 0.134 \\
Number of meals & 0.890 & 0.008 \\
Child order & 1.007 & 0.051 \\
Family size & 1.155 & 0.023 \\
Breakfast and/or morning snacks & 1.150 & 0.002 \\
Mid-day snack & -0.552 & 0.238 \\
BREAKFAST+ NUMBER OF MEAL & 1.349 & 0.008 \\
Snack before sleep & 0.104 & 0.661 \\
Meals on time & 1.098 & 0.000 \\
Snacks between meals & -0.005 & 0.987 \\
Egg No/Yes & 1.279 & 0.000 \\
Dairy No/Yes & 1.556 & 0.000 \\
Vegetable No/Yes & -1.149 & 0.073 \\
Fruit No/Yes & 0.228 & 0.599 \\
Soft drink No/Yes & -0.779 & 0.007 \\
Chips No/Yes & 0.024 & 0.943 \\
Candy No/Yes & 0.026 & 0.914 \\
Father education cat & -1.136 & 0.009 \\
Mother education cat & -1.007 & 0.005 \\
Family income & 1.382 & 0.007 \\
Mother job cat & 0.165 & 0.387 \\
Constant & 0.831 & 0.730 \\
\hline
\end{tabular}

The WHO estimates that malnutrition accounts for $45 \%$ of child mortality worldwide [24]. In developing countries, $52 \%$ of school-aged children are stunted [25].

The Egypt Demographic and Health Survey 2008 (EDHS 2008) revealed that the prevalence of stunting among children under 5 years was $28.9 \%$, while in the EDHS 2014, it was found to be 21\% [5]. Height-forage used to indicate past nutritional deficits as it reflects a child's nutritional history. Stunting is a long-term process beginning from early life, so children who were under five in 2014 are today's school-aged children. Detecting prevalence of stunting in these age groups, detecting the associated factors, and whether applying school feeding programs, promoting awareness, and improving social factors can have a beneficial effect on the catch-up of those children, are important factors to investigate to reach our targets of SDGs.

In our study, the prevalence of stunting was $7.8 \%$ which is less than many previous Egyptian studies. A school-based cross-sectional survey was conducted on children aged 6-17 years in an Egyptian village revealed that stunting among children was $34.2 \%$. Father employment, which reflects family income, and dietary habits, were from the high priority factors in this study [26]. A study that was done in Egypt revealed varied prevalence of stunted ranging $9.8 \%$ of urban and $12.8 \%$ of rural primary school-aged children [27]. They attributed this to bad feeding practices and a lack of awareness among children and parents. Another study in Egypt estimated that the prevalence of stunting and severely stunted growths was $11.3 \%$ and $1.15 \%$, respectively. This was significantly associated with rural location, poorly educated mothers, and birth order $\geq 4$ [28]. In the current study, there were many dietary behaviors associated with stunting. Skipping breakfast and having $<3$ meals per day carried more than 4 times the risk of being stunted than those who had breakfast and their number of meals were more than three per day. There are many Egyptian studies supporting these findings and at the same time suggesting that school feeding programs and breakfast resulted in improvements in children's health and nutrition when provided for a long period [6], [7], [8], [9], [10], [11]

Egypt is on course to meet the global targets of under-five stunting which is less than that of developing countries by $25 \%$ [29]. Such a target could not be achieved without educating mothers about the role of breastfeeding during the first 2 years of life in improving the health and development of infants [8], [9], [10], [11]. Meanwhile, to achieve SDG for decreasing stunting in Egypt, community-based programs for empowering women is indicated as it proved to be successful for rural communities in Egypt for controlling both communicable and non-communicable diseases and for enhancing progress toward a better quality of life [30], [31], [32], [33].

FAO statistics in the year 2018 revealed that there is a reduction in the overall percentage of the undernourished population from $5.1 \%$ to $4.5 \%$ along the years 2001 to 2017 . This was in consistent with the increase of the availability of fruits and vegetables per gram was 930 in 2008 and 812 in 2013 [34]. Tomorrow's generation grows up healthier is an initiative falling under the Egyptian President's "100 Million Health" campaign. The initiative will provide free healthcare to anyone suffering from conditions associated with a bad or unbalanced diet such as anemia, obesity, or stunted growth as well as raising awareness on how to avoid such problems in the future [35].

The school feeding program in Egypt is an initiative from the Egyptian government that can lower stunting percentage in the long run [7]. Preventing stunting is from the targets included in Egypt's national plan that requires general improvements in maternal and child nutrition. Decreasing the percentage of stunted children is also one of the Egyptian indicators for SDG 2 (zero hunger) [36]. Meanwhile, the role of primary health care in educating women about healthy food is considered a woman and child right and is mandatory, especially in rural communities [37], [38].

The social enabling factors that were found to affect physical growth included family size and income, mother's education, and the order of the child among his siblings. In this study, it was found that large family size was a significant factor for stunting where the majority of stunted children $(74.07 \%)$ belonged to large-sized families. This can be interpreted by that large family size leads to decreased child's share of family income as well as diminished child's share of daily food. Family income is related mainly to father income as in most families, the father is the money earner. It was found that the majority of stunted children were from lowincome families (73.33\%) compared to normal children where $54.08 \%$ were from middle-income families.

Another reason may be that large families depend on school meals for feeding their children and direct resources formerly used to feed their children 
toward other household needs, which could ultimately improve the welfare of the family as a whole. Poverty negatively affected a child's growth, both in utero and in early childhood.

Among the underlying causes of malnutrition in Egypt is food insecurity besides poor access to a balanced diet among the poor, poor dietary habits, as well as lifestyle and lack of nutritional awareness across the population [39].

Parental characteristics are considered one of the non-economic factors that may result in variability in children's diets and their nutritional status. There are many factors that were proved to be significantly associated with increased child height including higher maternal education levels, higher maternal height, higher family income, and a higher percentage of energy intake from protein [40], [41]. The results of the present study indicate that mother's education is an important social factor affecting physical growth where it was found that children of illiterate mothers were more affected by stunting $(77.78 \%)$. The influence of maternal education - the years of schooling achieved by the mother in the local school system - proved to be profound and dominated upon different aspects of diet and the nutritional status of children. The fact that higher levels of education for women in developing countries translate into better nutrition for offspring may be due to that more schooling leads to greater exposure to nutrition principles. It was also hypothesized that more educated women in developing countries are more receptive or have a higher ability to understand information about child care and nutrition [8], [42], [43], [44] and are more able to maximize utilization of existing family and community resources for available governmental primary health care services [45], [46]. Moreover, the linkage between exclusive breastfeeding with higher levels of maternal education was documented among studies targeted infants and preschool children from developing countries [8], [9], [10], [11], [43]. Meanwhile, higher levels of maternal intelligence promote better offspring health as it influences increased usage of adaptive behavior strategies. Results of a previous study done in Egypt indicated that toddlers whose mothers had higher levels of education had higher-quality diets, even after controlling socioeconomic status factors [11].

\section{Conclusion}

Nutrition is a fundamental aspect for health and development in school-age children. There are many dietary behaviors associated with short stature as skipping breakfast, having $<3$ meals per day, not having meals on time, and taking non-nutritive food as soft drinks. Enabling social factors included family size and income and mother's education. Improvement of those factors can lead to a decreasing prevalence of short stature.

It is recommended to disseminate knowledge about healthy eating and good health practices and how to make use of the available resources through massive campaigns, especially in rural and poor areas.

\section{Strengths of the study}

Our study is characterized by being a facilitybased one on representing three different geographical areas with a very large sample size (1740 child), with a high confidence level of $98 \%$ and low two-sided margin of error (0.03). As the role of the paternal and maternal parameters on child development is well evident in many Egyptian studies, the influence of these parameters was studied in the current manuscript.

\section{Limitation of the study}

This study was limited to investigate the dietary behavior and social factors on stunting. Another limitation is that the cognitive capabilities and behavior of school-aged children were not studied.

\section{Acknowledgments}

The authors express their thanks and appreciation to the studied schoolchildren and their parents for their willingness to participate and cooperate during the implementation of the study.

\section{References}

1. United Nations Children's Fund. Every Child, Nutrition, Appropriate Nutrition is Crucial for Optimal Growth and Development of Children; 2019. Available from: https://www. unicef.org/egypt/nutrition. [Last accessed on 2020 Jan 30.

2. United Nations. Sustainable Development Goals. Available from https://www.sustainabledevelopment.un.org/?menu=1300. [Last accessed on 2020 Jan 30].

3. Black RE, Heidkamp R. Causes of stunting and preventive dietary interventions in pregnancy and early childhood. Nestle Nutr Inst Workshop Ser. 2018;89:105-13. https://doi. org/10.1159/000486496

PMid:29991036

4. UNICEF, WHO, World Bank Group. Levels and Trends in Child Malnutrition. UNICEF/WHO/World Bank Group Joint Child Malnutrition Estimates. Key Findings of the 2017 Edition. Geneva: United Nations Children's Fund, World Health Organization, World Bank Group; 2017 Available from: http:/ www.who.int/nutgrowthdb/jme_brochoure2017.pdf?ua=1. [Last accessed on 2018 Jan 22]. https://doi.org/10.1093/ ww/9780199540884.013.u288893 
5. Ministry of Health and Population. El-Zanaty and Associates, ICF International. Egypt Demographic and Health Survey. Cairo, Maryland: Ministry of Health and Population, ICF International; 2015. Available from: https://www.dhsprogram.com/pubs/pdf/ FR302/FR302.pdf. [Last accessed on 2018 Aug 28].

6. Salah EM, Khalifa AG, Metwally AM, Hamid NA, Hussien HA, Moneer ZM. The impact of school snacks on cognitive function of primary school children in Egypt. J Appl Sci Res. 2012;8:5639-50.

7. Metwally AM, El-Sonbaty MM, El Etreby LA, Salah El-Din EM, Abdel Hamid N, Hussien HA, et al. Impact of national Egyptian school feeding program on growth, development and school achievement of school children. World J Pediatr. 2020;16:393400. https://doi.org/10.1007/s12519-020-00342-8

8. El-Din EM, Elabd MA, Nassar MS, Metwally AM, Abdellatif GA, Rabah TM, et al. The interaction of social, physical and nutritive factors in triggering early developmental language delay in a sample of Egyptian children. Open Access Maced J Med Sci. 2019;7(17):2767-74. https://doi.org/10.3889/oamjms.2019.642 PMid:31844434

9. El Din EM, Rabah TM, Metwally AM, Nassar MS, Elabd MA, Shaalan $A$, et al. Potential risk factors of developmental cognitive delay in the first two years of life. Open Access Maced J Med Sci. 2019;7(12):2024-30. https://doi.org/10.3889/oamjms.2019.566 PMid:31406549

10. Kandeel WA, Rabah TM, Zeid DA, El-Din EM, Metwally AM, Shaalan A, et al. Determinants of exclusive breastfeeding in a sample of Egyptian infants. Open Access Maced J Med Sci. 2018;6(10):1818-23. https://doi.org/10.3889/oamjms.2018.359 PMid:30455755

11. Metwally AM, Salah El-Din EM, Shehata MA, Shaalan A, EI Etreby LA, Kandeel WA, et al. Early life predictors of socioemotional development in a sample of Egyptian infants. PLoS One. 2016;11(7):e0158086. https://doi.org/10.1371/journal. pone. 0158086

PMid:27379907

12. Bogale TY, Bala ET, Tadesse M, Asamoah BO. Prevalence and associated factors for stunting among 6-12 years old school age children from rural community of Humbo district, Southern Ethiopia. BMC Public Health. 2018;18(1):653. https://doi. org/10.1186/s12889-018-5561-z PMid:29793479

13. Fleiss JL, Levin B, Paik MC. Statistical Methods for Rates and Proportions. $3^{\text {rd }}$ ed. New York: John Wiley and Sons; 2003.

14. Newcombe RG. Two-sided confidence intervals for the single proportion: Comparison of seven methods. Stat Med. 1998;17:857-72. https://doi.org/10.1002/ (sici)1097-0258(19980430)17:8<857::aid-sim777>3.0.co;2-e

15. Central Agency for Public Mobilization and Statistics; 2018. Available from: https://www.capmas.gov.eg. [Last accessed on 2020 Jul 23].

16. Lohman TG, Roche AF, Martorell R. Anthropometric Standardization Reference Manual. Champaign, IL: Human Kinetics Publishers; 1988.

17. World Health Organization. AnthroPlus for Personal Computers. Manual Software for Assessing Growth of the World's Children and Adolescents 2009. Geneva: World Health Organization; 2009. Available from: http://www.who.int/growthref/tools/en. [Last accessed on $2018 \mathrm{Jul} 05$ ].

18. World Health Organization. Physical Status: The Use and Interpretation of Anthropometry. Report of a WHO Expert Committee, Technical Report Series No. 854. Geneva: World Health Organization; 1995a. https://doi.org/10.1037/ e412352004-001

19. Council for International Organizations of Medical Science a Nongovernmental Organization in Official Relations with
WHO. International Ethical Guidelines for Biomedical Research Involving Human Subjects. Geneva: Council for International Organizations of Medical Science; 2016.

20. Georgiev GZ. One-tailed vs Two-tailed Tests of Significance in A/B Testing; 2017. Available from: http://www.blog.analyticstoolkit.com/2017/one-tailed-two-tailed-tests-significance-abtesting. [Last accessed on 2018 Apr 28]. https://doi.org/10.5005/ jp/books/11289_5

21. Georgiev GZ. Odds Ratio Calculator. Available from: https:// www.gigacalculator.com/calculators/odds-ratio-calculator.php. [Last accessed 2020 Apr 03].

22. SPSS IBM. Released. IBM SPSS Statistics for Windows, Version 24.0. Armonk, NY: IBM; 2016. https://doi. org/10.4324/9781003117452-4

23. Victora CG, Fall C, Hallal PC, Martorell R, Richter L, Sachdev HS, Maternal Group CUS. Maternal and child undernutrition: Consequences for adult health and human capital. Lancet. 2008;371(9609):340-57. https://doi.org/10.1016/ s0140-6736(07)61692-4

PMid:18206223

24. World Health Organization. Children: Reducing Mortality Geneva: World Health Organization; 2019. Available from: https://www.who.int/news-room/fact-sheets/detail/childrenreducing-mortality. [Last acessed on 2020 Jan 18].

25. Report of the Standing Committee on Nutrition at its Thirty-Third Session, Official Records (United Nations General Assembly). Geneva: World Health Organization; 2006. Available from: https://www.un-ilibrary.org/women-and-gender-issues/reportof-the-committee-on-the-elimination-of-discrimination-againstwomen_f76ba401-en. [Last acessed on 2020 Jan 22]. https:// doi.org/10.18356/a105bd8b-en

26. Abdel Wahed WY, Hassan SK, Eldessouki R. Malnutrition and its associated factors among rural school children in fayoum Governorate, Egypt. J Environ Public Health. 2017;2017:4783791. https://doi.org/10.1155/2017/4783791 PMid:29201063

27. Emam S, Mostafa R, Wassef O. Assessment of nutritional status of some primary school children and their awareness in slum areas. Alexandria J Pediatr. 2005;19(1):113-9.

28. Abd El-Fatah NK, Abu-Elenin MM. Prevalence of stunting, overweight and obesity among Egyptian primary school children in behera governorate. Food Public Health. 2019;9(3):84-93.

29. Global Nutrition Report, Egypt. Country Overview; 2019. Available from: https://www.globalnutritionreport.org/resources/ nutrition-growth-commitment-tracking. [Last accessed on 2020 Jan 31].

30. UNICEF. The State of the World's Children 2019. Children, Food and Nutrition: Growing Well in a Changing World. New York: UNICEF; 2019. Available from: https://www.unicef.org/ media/60806/file/SOWC-2019.pdf. [Last accessed on 2020 Jan 31]. https://doi.org/10.36072/cp.3

31. Metwally AM, Soliman M, Abdelmohsen AM, Kandeel WA Saber M, Elmosalami DM, et al. Effect of counteracting lifestyle barriers through health education in Egyptian Type 2 diabetic patients. Open Access Maced J Med Sci. 2019;7(17):2886-94. https://doi.org/10.3889/oamjms.2019.624 PMid:31844454

32. Shiha G, Metwally AM, Soliman R, Elbasiony M, Mikhail NN Easterbrook P. An educate, test, and treat programme to reduce hepatitis $\mathrm{C}$ in Egypt: Results from a communitybased demonstration project. Lancet Gastroenterol Hepatol. 2018;3(11):778-89. https://doi.org/10.1016/ s2468-1253(18)30139-0 PMid:30030068

33. Salama E, Sami SM, Said ZN, Salama SI, Rabah TM, AbdelLatif GA, et al. Early and long term anamnestic response to HBV 
booster dose among fully vaccinated Egyptian children during infancy. Vaccine. 2018;36:2005-11. https://doi.org/10.1016/j. vaccine.2018.02.103

PMid:29530634

34. Food and Agriculture Organization of the United Nations. FAO STAT; 2018 Available from: http://www.fao.org/faostat/ en/\#home. [Last accessed on 2020 Jan 31]. https://doi. org/10.18356/0170ea0f-en

35. Nile FM. Spotlight President El-Sisi's "Better Health" Initiative Uses a Wholesome Rap to Encourage Youth to Eat Better and Live Healthier; 2019. Available from: https://www.nilefm.com/ digest/article/4858/president-el-sisi-s-better-health-initiativeuses-a-wholesome-rap-to-encourage-youth-to-eat-betterlive-healthier. [Last accessed on 2020 Jan 31]. https://doi. org/10.26419/pia.00037.005

36. Ministry of Planning, Monitoring andAdministrative Reform. Egypt's Voluntary National Review; 2018. Available from: https://www. sustainabledevelopment.un.org/content/documents/20269EGY VNR_2018_final_with_hyperlink_9720185b45d.pdf. [Last accessed on 2020 Mar 02].

37. Metwally AM, Saad A, Ibrahim NA, Emam HM, El-Etreby LA. Monitoring progress of the role of integration of environmental health education with water and sanitation services in changing community behaviors. Int J Environ Health Res. 2007;17(1):6174. https://doi.org/10.1080/09603120600937856

PMid:17365081

38. Metwally AM, Ibrahim NA, Saad A, Abu el-Ela M. Improving rural women role in health and environmental issues. Int J Environ Health Res. 2006;16(2):133-44. https://doi. org/10.1080/09603120500539208

39. Maternal and Child Nutrition Study Group. Maternal and child nutrition: Building momentum for impact. Lancet. 2013;382:373-5.
40. World Health Organization. Reducing Stunting in Children: Equity Considerations for Achieving the Global Nutrition Targets 2025. Geneva: World Health Organization; 2018.

41. Zhang $\mathrm{Y}$, Wang $\mathrm{H}$, Wang $\mathrm{X}$, Wang $\mathrm{Y}$, Zhou $\mathrm{H}$. The association between urbanization and child height: $A$ multilevel study in China. BMC Public Health. 2019;19(1):569.

42. Mazengia L A, Biks A. G. Predictors of stunting among school-age children in Northwestern Ethiopia. J Nutr Metab. 2018;2018:7521751. https://doi.org/10.1155/2018/7521751 PMid:30327729

43. Woldie GA, Woldie H, Mekonnen FA, Gonete KA, Sisay M Undernutrition and associated factors among urban children aged 24-59 months in Northwest Ethiopia: A community based cross sectional study. BMC Pediatr. 2019;19:214. https://doi. org/10.1186/s12887-019-1595-3

44. Van Rossem R, Pannecoucke I. Poverty and a child's height development during early childhood: A double disadvantage? A study of the 2006-2009 birth cohorts in Flanders. PLoS One. 2019;14(1):e0209170. https://doi.org/10.1371/journal. pone.0209170

PMid:30601853

45. Metwally AM, Saleh RM, El-Etreby LA, Salama SI, Aboulghate A, Amer HA, et al. Enhancing the value of women reproductive rights through community based interventions in upper Egypt governorates: A randomized interventional study. Int J Equity Health. 2019;18(1):146. https://doi.org/10.1186/ s12939-019-1042-y

46. Metwally AM, Abdel-Latif GA, Mohsen A, El-Etreby L, Elmosalami DM, Saleh RM, et al. Strengths of community and health facilities based interventions in improving women and adolescents' care seeking behaviors as approaches for reducing maternal mortality and improving birth outcome among low income communities of Egypt. BMC Health Serv Res. 2020;20:592. https://doi.org/10.1186/s12913-020-05412-1 